\title{
[Supporting Information]
}

\section{A Thiolato-Bridged $\mathrm{Ru}^{\mathrm{II}} \mathrm{Ag}^{\mathrm{I}} \mathrm{Ru}^{\mathrm{II}}$ Trinuclear Complex Composed of Bis(bipyridine)ruthenium(II) Units with Chelating 2-Aminoethanethiolate: Conversion to a Disulfide-Bridged Ru ${ }^{\text {II }} \mathbf{R u}^{\text {II }}$ Dinuclear Complex}

\begin{abstract}
Motoshi Tamura, Noriyuki Matsuura, Tatsuya Kawamoto, and Takumi Konno* Department of Chemistry, Graduate School of Science, Osaka University, Toyonaka, Osaka 560-0043, Japan
\end{abstract}

\section{Preparation of complexes.}

(a) $\left[\mathbf{A g}\left\{\mathbf{R u}(\mathbf{a e t})(\mathbf{b p y})_{2}\right\}_{2}\right]\left(\mathbf{P F}_{\mathbf{6}}\right)_{\mathbf{3}} \mathbf{( 1 )}$. To a solution of $0.20 \mathrm{~g}(0.38 \mathrm{mmol})$ of $\left[\mathrm{RuCl}_{2}(\mathrm{bpy})_{2}\right] \cdot 2 \mathrm{H}_{2} \mathrm{O}$ in $20 \mathrm{~mL}$ of $1: 1$ ethanol/water was added $0.24 \mathrm{~g}(1.16 \mathrm{mmol})$ of $\mathrm{AgClO}_{4}$. The mixture was refluxed for $20 \mathrm{~min}$ and then cooled to room temperature. The deposited $\mathrm{AgCl}$ was removed by filtration through celite. To the red-orange filtrate was added $0.09 \mathrm{~g}$ (1.20 mmol) of Haet. The mixture was refluxed for $6 \mathrm{~h}$ under an $\mathrm{N}_{2}$ atmosphere and then filtered. To the brown filtrate was added $2 \mathrm{~mL}$ of a $1 \mathrm{M}$ aqueous solution of $\mathrm{NH}_{4} \mathrm{PF}_{6}$, followed by storing in a refrigerator for 1 day. The resulting dark brown powder was collected by filtration, washed with cold water, and then dried in air. Yield: $0.18 \mathrm{~g}(62 \%)$. This complex was recrystallized from acetonitrile/ethanol/water (1:1:1).

Anal. Calcd for 1.2 $\mathrm{H}_{2} \mathrm{O}$ : C, 33.92; H, 3.11; N, 8.99\%. Found: C, 34.06; H, 3.12; N, 9.05\%. UV-vis $\left[\mathrm{CH}_{3} \mathrm{CN}, \lambda_{\max }, \mathrm{nm}\left(\varepsilon, 10^{3} \mathrm{~mol}^{-1} \mathrm{dm}^{3} \mathrm{~cm}^{-1}\right)\right]: 501$ (15.10), 455 $5^{\mathrm{sh}}(11.7), 350$ (14.18), 293 (90.50), 244 (46.68). ${ }^{13} \mathrm{C}$ NMR (125 MHz, acetonitrile- $\left.d_{3}\right): \delta 159.39,158.54,158.51$, $153.36,152.70,152.36,151.94,137.44,137.11,136.54,135.95,128.01,127.77,127.10$, $126.79,124.82,124.64,124.00,123.90,50.52,30.64$.

ES-MS $\left(\mathrm{CH}_{3} \mathrm{CN}, m / z, \%\right): 521.89$ ([Ru(aesi)(bpy $\left.\left.)_{2}\right]^{+}, 100\right), 489.95$ ([Ru(aet)(bpy $\left.\left.)_{2}\right]^{+}, 38.5\right)$, $363.02\left(\left[\mathrm{Ag}\left\{\mathrm{Ru}(\mathrm{aet})(\mathrm{bpy})_{2}\right\}_{2}\right]^{3+}, 11.7\right), 337.73\left(\left[\mathrm{Ag}\left\{\mathrm{Ru}(\right.\right.\right.$ aet $\left.)(\text { bpy })_{2}\right\}\left\{\mathrm{Ru}(\mathrm{aet})\left(\mathrm{CH}_{3} \mathrm{CN}\right)_{2-}\right.$ (bpy) $\left.\}]^{3+}, 29.4\right), 320.06\left(\left[\left\{\mathrm{Ru}(\text { aet })(\text { bpy })_{2}\right\} \mathrm{Ag}\left(\mathrm{CH}_{3} \mathrm{CN}\right)\right]^{2+}, 28.0\right)$. 
The cyclic voltammetry of $\mathbf{1}$ did not show any informative CV curves presumably because of the adhesion of silver on the surface of the electrode.

\section{(b) $\left[\operatorname{Ru}_{2}(\right.$ cysta $\left.)(b p y)_{4}\right]\left(P_{6}\right)_{4}(2)$.}

To a solution of $0.30 \mathrm{~g}(0.20 \mathrm{mmol})$ of $\left[\mathrm{Ag}\left\{\mathrm{Ru}(\mathrm{aet})(\mathrm{bpy})_{2}\right\}_{2}\right]\left(\mathrm{PF}_{6}\right)_{3}(\mathbf{1})$ in $60 \mathrm{~mL}$ of $1: 1$ acetonitrile/water was added $3 \mathrm{~mL}$ of $1 \mathrm{M} \mathrm{HCl}$. The mixture was stirred at room temperature for $1 \mathrm{~h}$, during which time the solution turned to red-brown. The deposited $\mathrm{AgCl}$ was removed by filtration through celite, and the filtrate was concentrated to ca. $30 \mathrm{~mL}$ with a rotary evaporator. The red-brown solution was chromatographed on an SP-Sephadex C-25 column $\left(\mathrm{Na}^{+}\right.$form, $\left.3 \mathrm{~cm} \times 30 \mathrm{~cm}\right)$. After the column had been washed with water, a brown band was eluted with a $0.3 \mathrm{M}$ aqueous solution of $\mathrm{NaCl}$. The red-brown eluate was concentrated to a small volume with a rotary evaporator and then ethanol was added to it. After removal of deposited $\mathrm{NaCl}$ by filtration, the filtrate was concentrated to ca. $4 \mathrm{~mL}$ with a rotary evaporator. To red-orange solution was added $1 \mathrm{~mL}$ of a $1 \mathrm{M}$ aqueous solution of $\mathrm{NH}_{4} \mathrm{PF}_{6}$, followed by storing in a refrigerator for 2 days. The resulting brown powder was collected by filtration, washed with cold water, and dried in air. Yield for $2 \cdot 2 \mathrm{H}_{2} \mathrm{O}: 0.26 \mathrm{~g}$ (81\%). Anal. Calcd for $2 \cdot 2 \mathrm{H}_{2} \mathrm{O}: \mathrm{C}, 33.13 ; \mathrm{H}, 3.03 ; \mathrm{N}, 8.78 \%$. Found: C, 33.14; H, 3.12; N,

8.71\%. UV-vis $\left[\mathrm{CH}_{3} \mathrm{CN}, \lambda_{\max }, \mathrm{nm}\left(\varepsilon, 10^{3} \mathrm{~mol}^{-1} \mathrm{dm}^{3} \mathrm{~cm}^{-1}\right)\right]: 434$ (17.80), 285 (77.08), $253^{\text {sh }}$ (35.7), 245 (38.66). ${ }^{13} \mathrm{C}$ NMR (150 MHz, acetonitrile- $\left.d_{3}\right): \delta 158.80,158.63,158.44,157.75$, $157.55,157.32$, 157.09, 156.86, 155.29, 154.69, 153.95, 153.71, 153.57, 153.36, 153.28, $153.14,152.98,152.33,152.23,140.98,140.59,140.34,140.19,140.03,139.46,139.24$, $130.21,129.56,129.45,128.93,128.69,128.50,128.42,128.09,126.26,126.15,125.81$, $125.74,125.39,125.21,125.00,124.77,124.66,44.33,44.25,43.68,43.34,40.98,40.77$. ES-MS $\left(\mathrm{CH}_{3} \mathrm{CN}, \mathrm{m} / \mathrm{z}\right): 635.02$ ([\{Ru(aet)(bpy $\left.\left.\left.)_{2}\right\}\left(\mathrm{PF}_{6}\right)\right]^{+}, 100\right), 490.17\left(\left[\mathrm{Ru}(\mathrm{aet})(\mathrm{bpy})_{2}\right]^{+}\right.$, 38.5). 


\section{(c) Conversion of 2 to 1 .}

To a solution of $0.10 \mathrm{~g}(0.06 \mathrm{mmol})$ of $2 \cdot 2 \mathrm{H}_{2} \mathrm{O}$ in $20 \mathrm{~mL}$ of $1: 1$ acetonitrile/water was added $0.2 \mathrm{~g}$ of $\mathrm{Zn}$ powder and $130 \mathrm{mg}(0.50 \mathrm{mmol})$ of $\mathrm{AgPF}_{6}$. The mixture was refluxed for 30 min under an $\mathrm{N}_{2}$ atmosphere, during which time the solution turned to dark brown. The reaction solution was filtered through celite, and to the filtrate was added $1 \mathrm{~mL}$ of a $1 \mathrm{M}$ aqueous solution of $\mathrm{NH}_{4} \mathrm{PF}_{6}$, followed by storing in a refrigerator for 3 days. The resulting dark brown powder was collected by filtration, washed with cold water, and dried in air. Yield for 1: $0.05 \mathrm{~g}(53 \%)$. 
Table S1. Crystallographic data of $\left[\mathrm{Ag}\left\{\mathrm{Ru}(\mathrm{aet})(\mathrm{bpy})_{2}\right\}_{2}\right]\left(\mathrm{PF}_{6}\right)_{3}(\mathbf{1})$ and $\left.\left[\mathrm{Ru}_{2} \text { (cysta)(bpy) }\right)_{4}\right]\left(\mathrm{PF}_{6}\right)_{4}(\mathbf{2})$.

\begin{tabular}{|c|c|c|}
\hline Complex & 1. $\mathrm{CH}_{3} \mathrm{CN}$ & $2 \cdot \mathrm{H}_{2} \mathrm{O}$ \\
\hline Formula & $\begin{array}{l}\mathrm{C}_{46} \mathrm{H}_{47} \mathrm{AgF}_{18} \mathrm{~N}_{11} \mathrm{P}_{3} \\
\mathrm{Ru}_{2} \mathrm{~S}_{2}\end{array}$ & $\mathrm{C}_{44} \mathrm{H}_{46} \mathrm{~F}_{24} \mathrm{~N}_{10} \mathrm{OP}_{4} \mathrm{Ru}_{2} \mathrm{~S}_{2}$ \\
\hline$M$ & 1562.99 & 1577.05 \\
\hline Crystal system & monoclinic & monoclinic \\
\hline Space group & $P 2_{1} / n$ & $P 2_{1} / c$ \\
\hline$a(\AA)$ & $13.801(7)$ & $13.802(6)$ \\
\hline$b(\AA)$ & $31.93(2)$ & $17.587(7)$ \\
\hline$c(\AA)$ & $14.241(8)$ & $12.701(5)$ \\
\hline$\beta(\operatorname{deg})$ & $116.44(2)$ & $114.890(13)$ \\
\hline $\mathrm{V}\left(\AA^{3}\right)$ & $5620(5)$ & 2797(2) \\
\hline$T(\mathrm{~K})$ & $200(2)$ & $200(2)$ \\
\hline $\mathrm{Z}$ & 4 & 2 \\
\hline$\lambda(\AA)$ & 0.71075 & 0.71075 \\
\hline$\rho_{\text {calcd }}\left(\mathrm{g} \mathrm{cm}^{-3}\right)$ & 1.847 & 1.873 \\
\hline$\mu\left[\mathrm{cm}^{-1}\right]$ & 11.41 & 8.57 \\
\hline$R^{a}(I>2 \sigma(I))$ & 0.040 & 0.074 \\
\hline$R \mathrm{w}^{b}(I>2 \sigma(I))$ & 0.069 & 0.146 \\
\hline$R^{a}$ (all data) & 0.091 & 0.126 \\
\hline$R \mathrm{w}^{b}$ (all data) & 0.074 & 0.168 \\
\hline GOF & 0.725 & 1.022 \\
\hline
\end{tabular}

${ }^{a} R=\Sigma|(|F \mathrm{O}|-|F \mathrm{c}|)| / \Sigma(|F \mathrm{O}|)$.

${ }^{b} R_{\mathrm{W}}=\left[\Sigma w\left(\left|F_{\mathrm{O}}\right|-\left|F_{\mathrm{C}}\right|\right)^{2} / \Sigma w\left(\left|F_{\mathrm{O}}{ }^{2}\right|\right)\right]^{1 / 2}, w=1 / \sigma^{2}\left(F_{\mathrm{O}}\right)$. 
Figure S1. VT ${ }^{1} \mathrm{H}$ NMR spectra of complex 1 in acetonitrile- $d_{3}$.

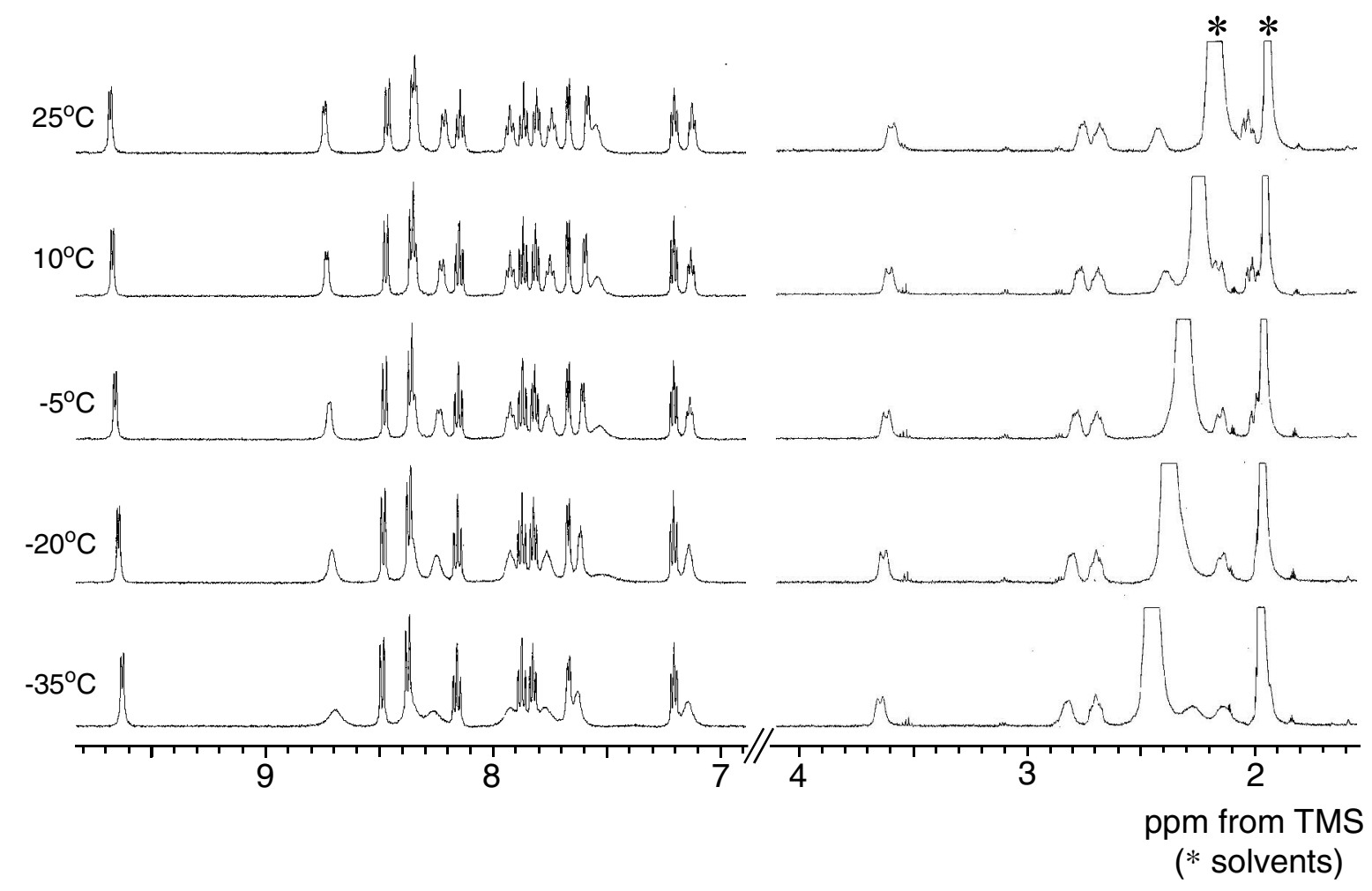


Figure S2. ${ }^{13} \mathrm{C}$ NMR spectrum of $\mathbf{1}$ in acetonitrile- $d_{3}$ at $25^{\circ} \mathrm{C}$.

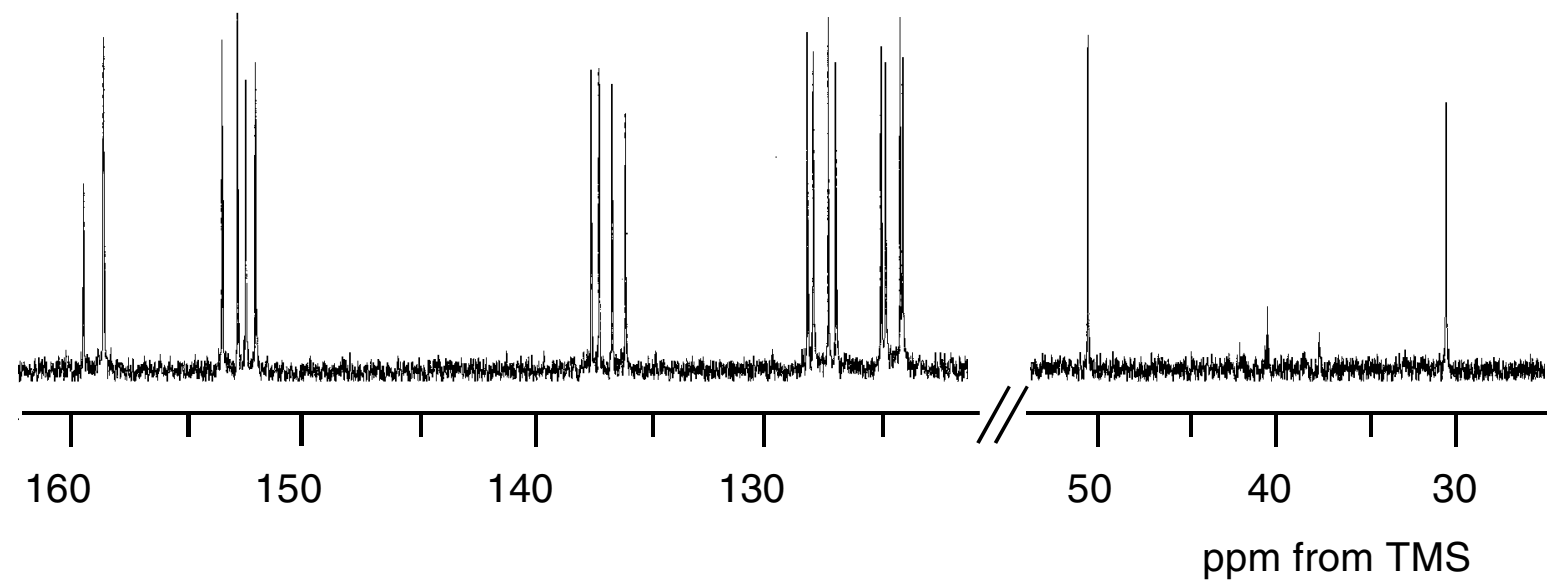


Figure S3. VT ${ }^{1} \mathrm{H}$ NMR spectra of complex 2 in acetonitrile- $d_{3}$.

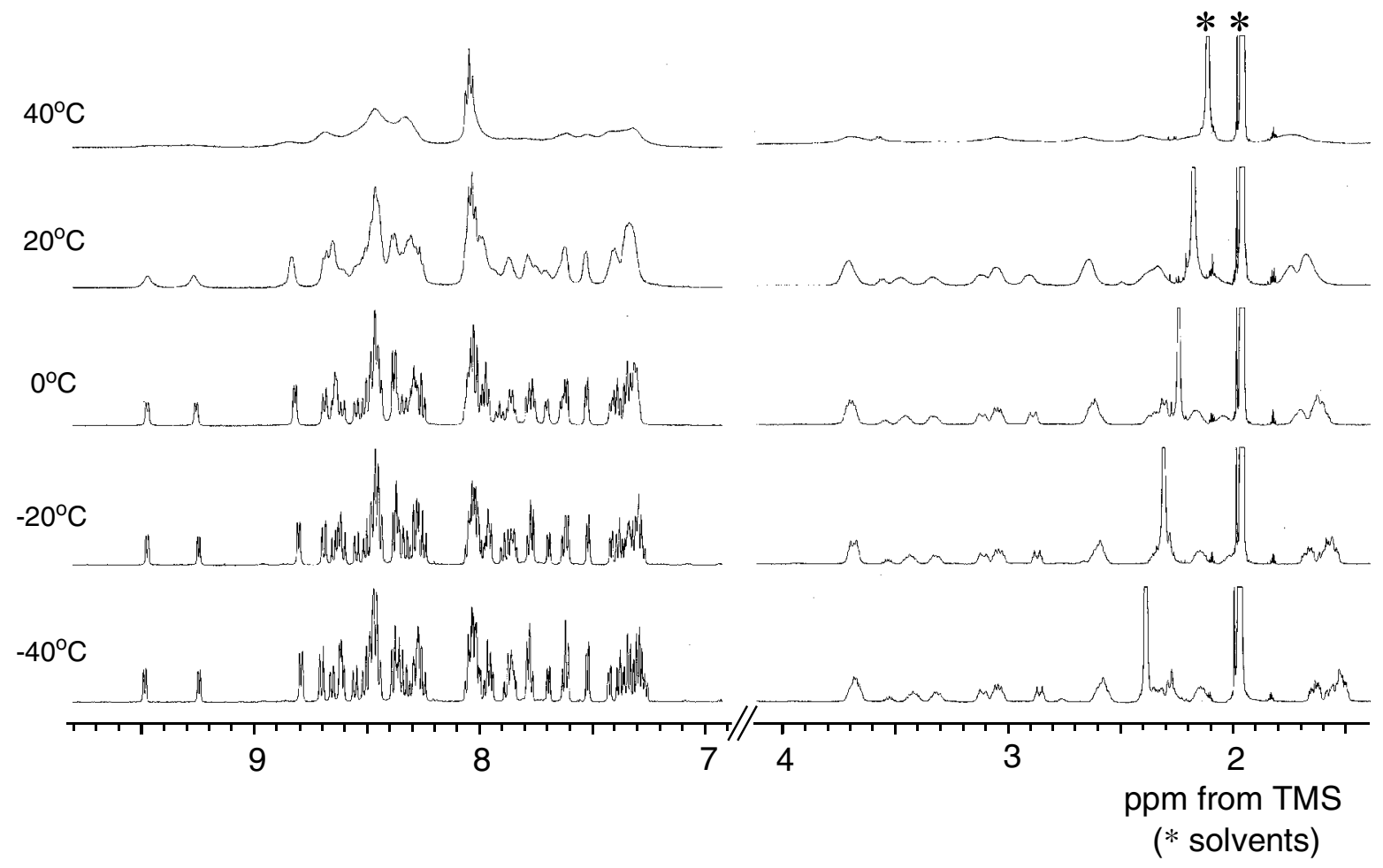


Figure S4. ${ }^{13} \mathrm{C}$ NMR spectrum of 2 in acetonitrile- $d_{3}$ at $-30{ }^{\circ} \mathrm{C}$.

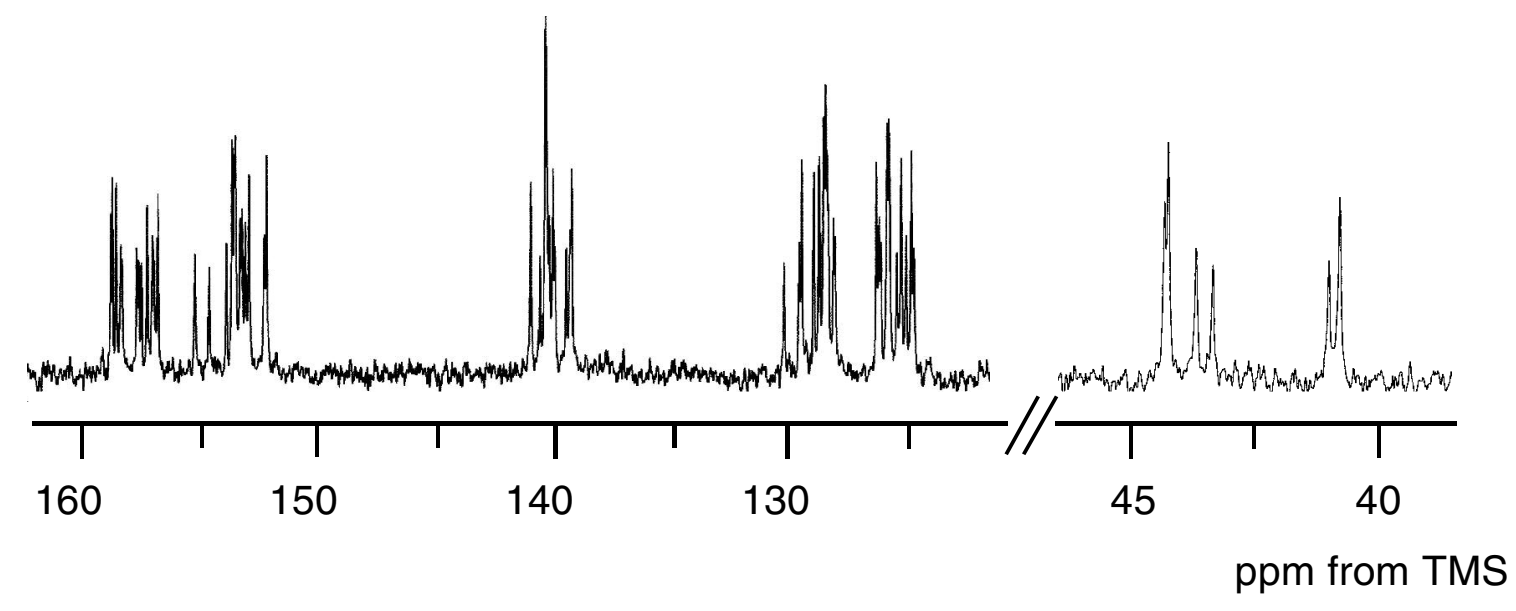


Figure S5. ES-MS spectrum of $\mathbf{1}$ in acetonitrile. Found and calcd for $\left[\mathrm{Ag}\left(\mathrm{CH}_{3} \mathrm{CN}\right)\left\{\mathrm{Ru}(\text { aet })(\text { bpy })_{2}\right\}\right]^{2+}$ (a), $\left[\mathrm{Ag}\left\{\mathrm{Ru}(\text { aet })(\text { bpy })_{2}\right\}\left\{\mathrm{Ru}(\text { aet })\left(\mathrm{CH}_{3} \mathrm{CN}\right)_{2} \text { (bpy) }\right\}\right]^{3+}$ (b), $\left[\mathrm{Ag}\left\{\operatorname{Ru}(\mathrm{aet})(\mathrm{bpy})_{2}\right\}_{2}\right]^{3+}(\mathrm{c}),\left[\operatorname{Ru}(\mathrm{aet})(\mathrm{bpy})_{2}\right]^{+}(\mathrm{d})$, and $\left[\mathrm{Ru}(\mathrm{aesi})(\mathrm{bpy})_{2}\right]^{+}(\mathrm{e})$.
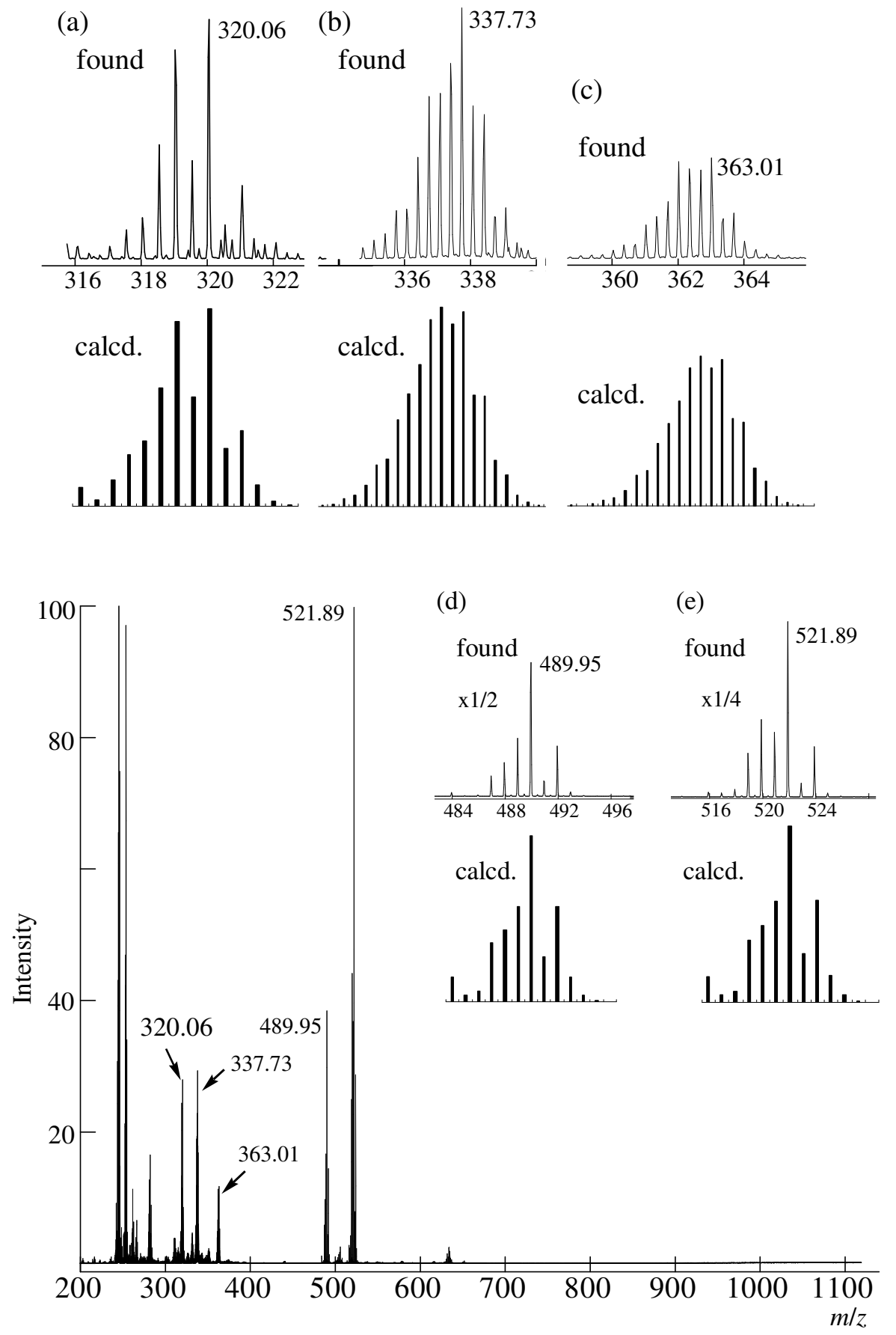
Figure S6. ES-MS spectrum of 2 in acetonitrile. Found for the signals centered at $m / z=$ 490.17 (a), calcd for $\left[\mathrm{Ru}(\mathrm{aet})(\mathrm{bpy})_{2}\right]^{+}$(b), found for the signals centered at $m / z=635.02$ (c), calcd for $\left[\left\{\mathrm{Ru}(\mathrm{aet})(\mathrm{bpy})_{2}\right\}\left(\mathrm{PF}_{6}\right)\right]^{+}(\mathrm{d})$, and calcd for $\left[\left\{\left\{\mathrm{Ru}(\mathrm{bpy})_{2}\right\}_{2}(\mu \text {-cysta })\right\}\left(\mathrm{PF}_{6}\right)_{2}\right]^{2+}(\mathrm{e})$.

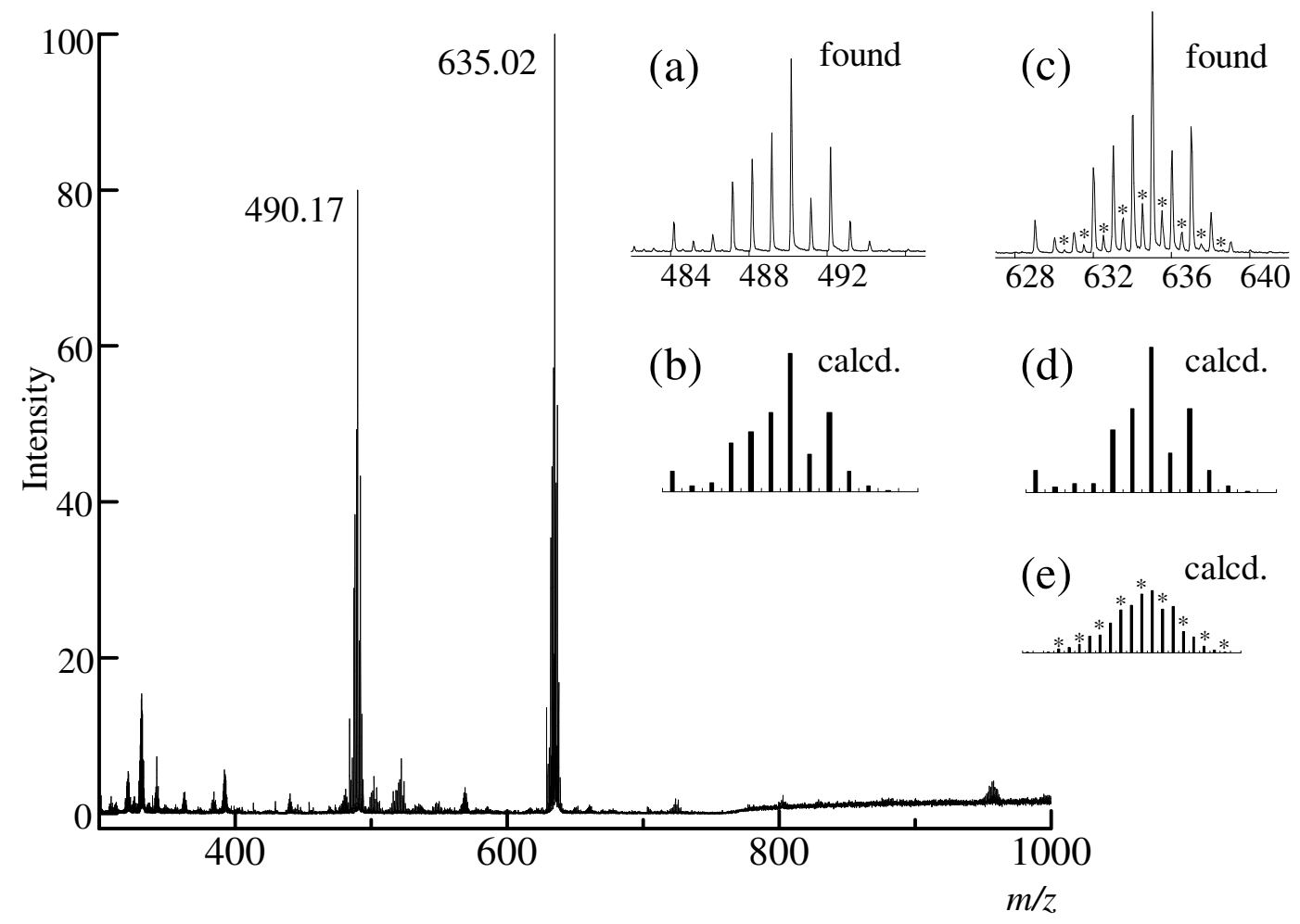


Figure S7. Cyclic voltammogram of 2 in acetonitrile $/ 0.1 \mathrm{M}\left[\mathrm{Bu}_{4} \mathrm{~N}\right] \mathrm{PF}_{6}$ at $25{ }^{\circ} \mathrm{C}$ with a scan rate of $100 \mathrm{mV} \mathrm{s}^{-1}$. The complex concentration is $0.5 \mathrm{mM}$.

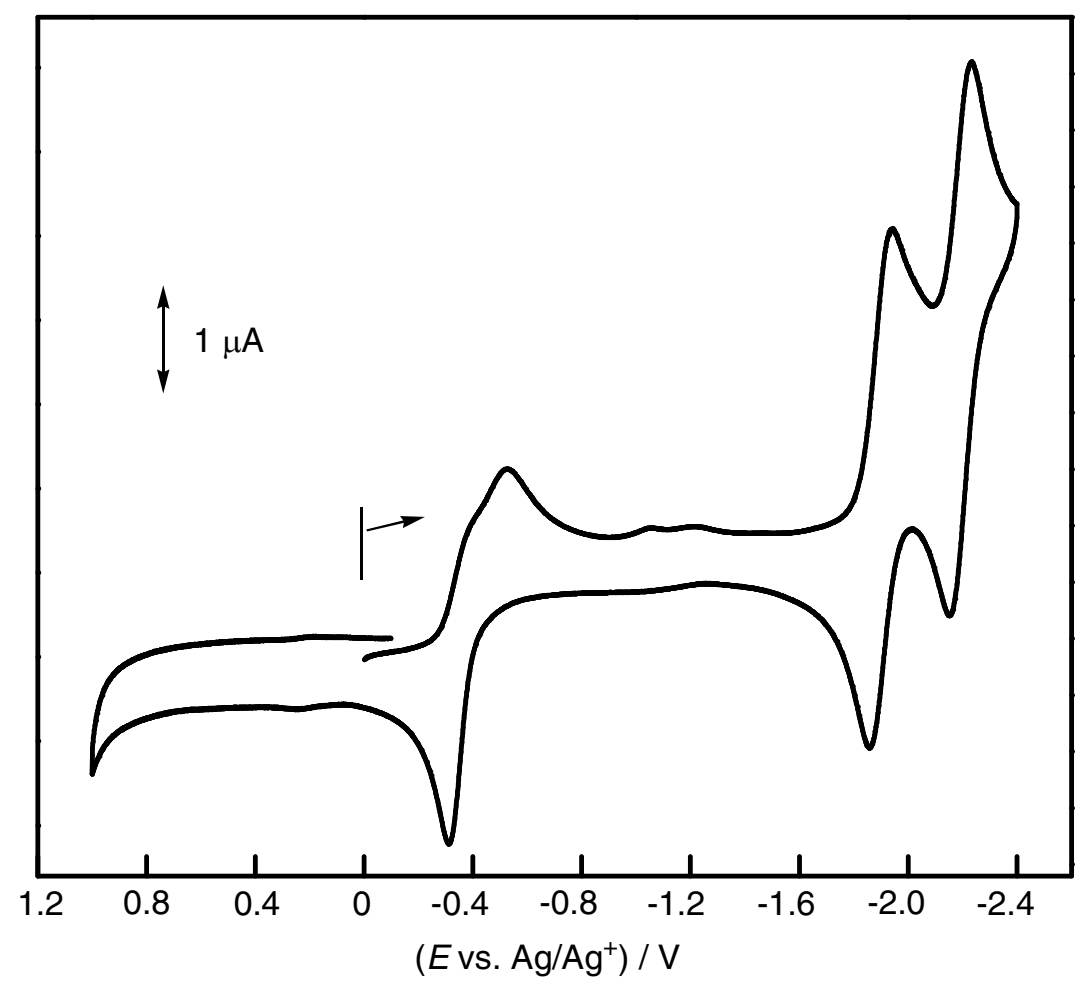


Figure S8. Diffuse reflectance spectrum of the solid sample of $\mathbf{1}$.

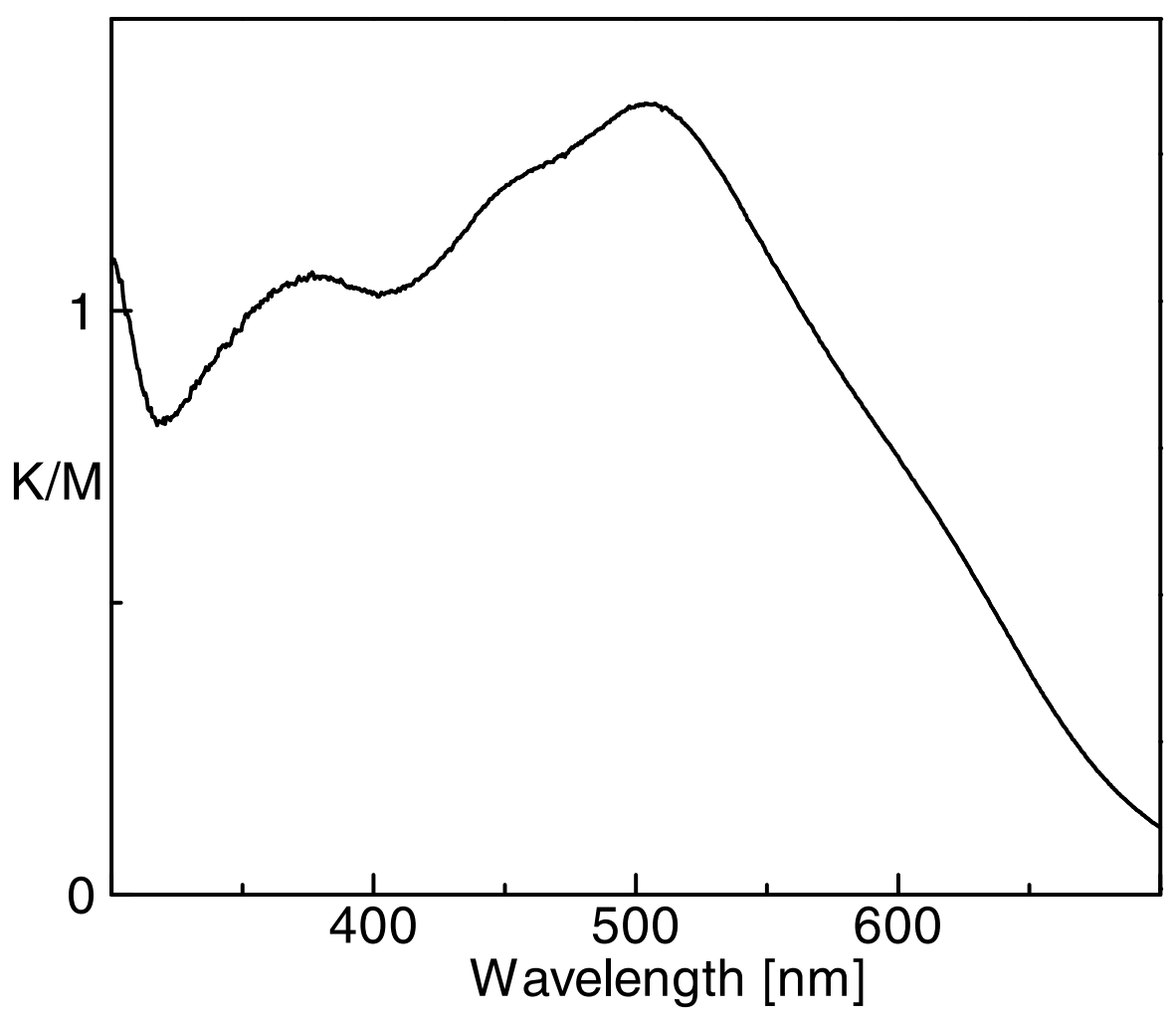


Figure S9. Diffuse reflectance spectrum of the solid sample of 2.

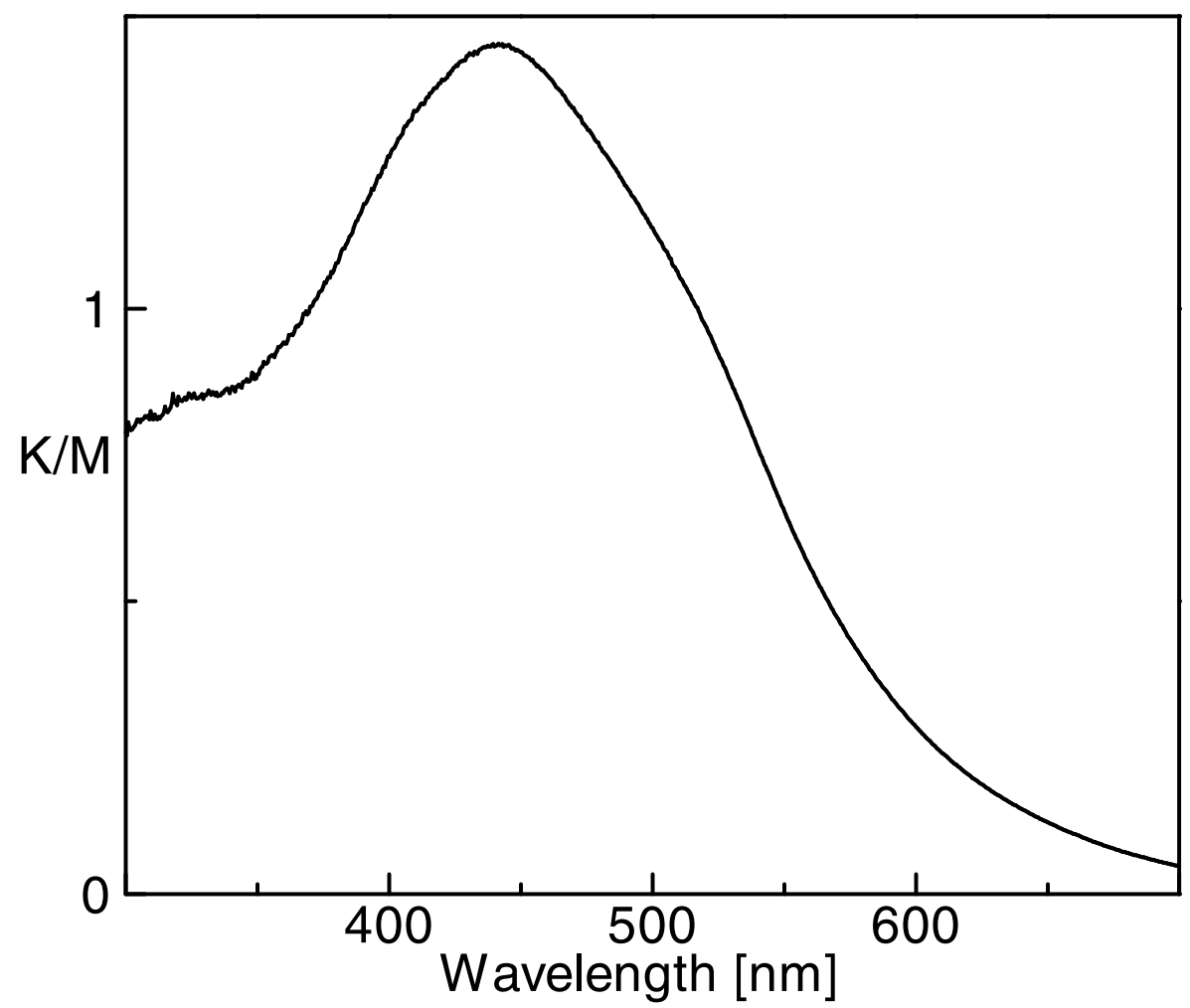


Scheme S1. Summary of the previous works.

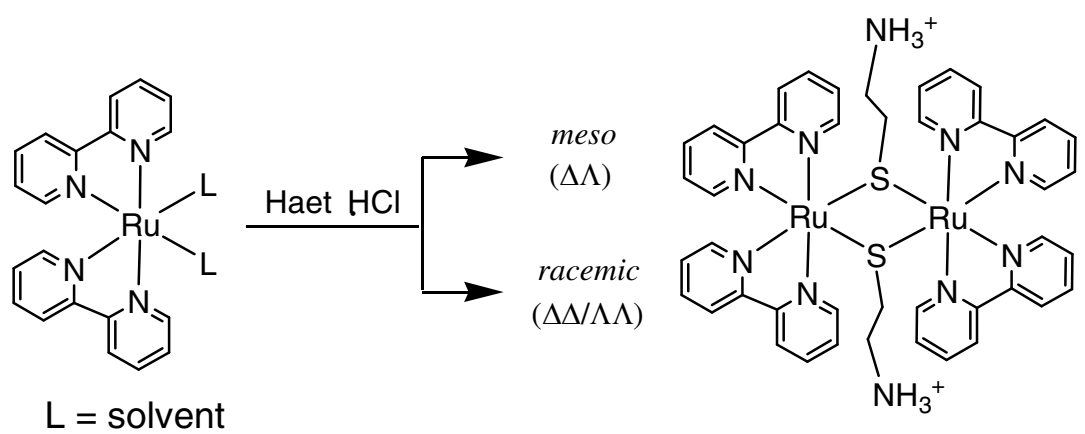

Chem. Lett. 2005, 34, 1252.
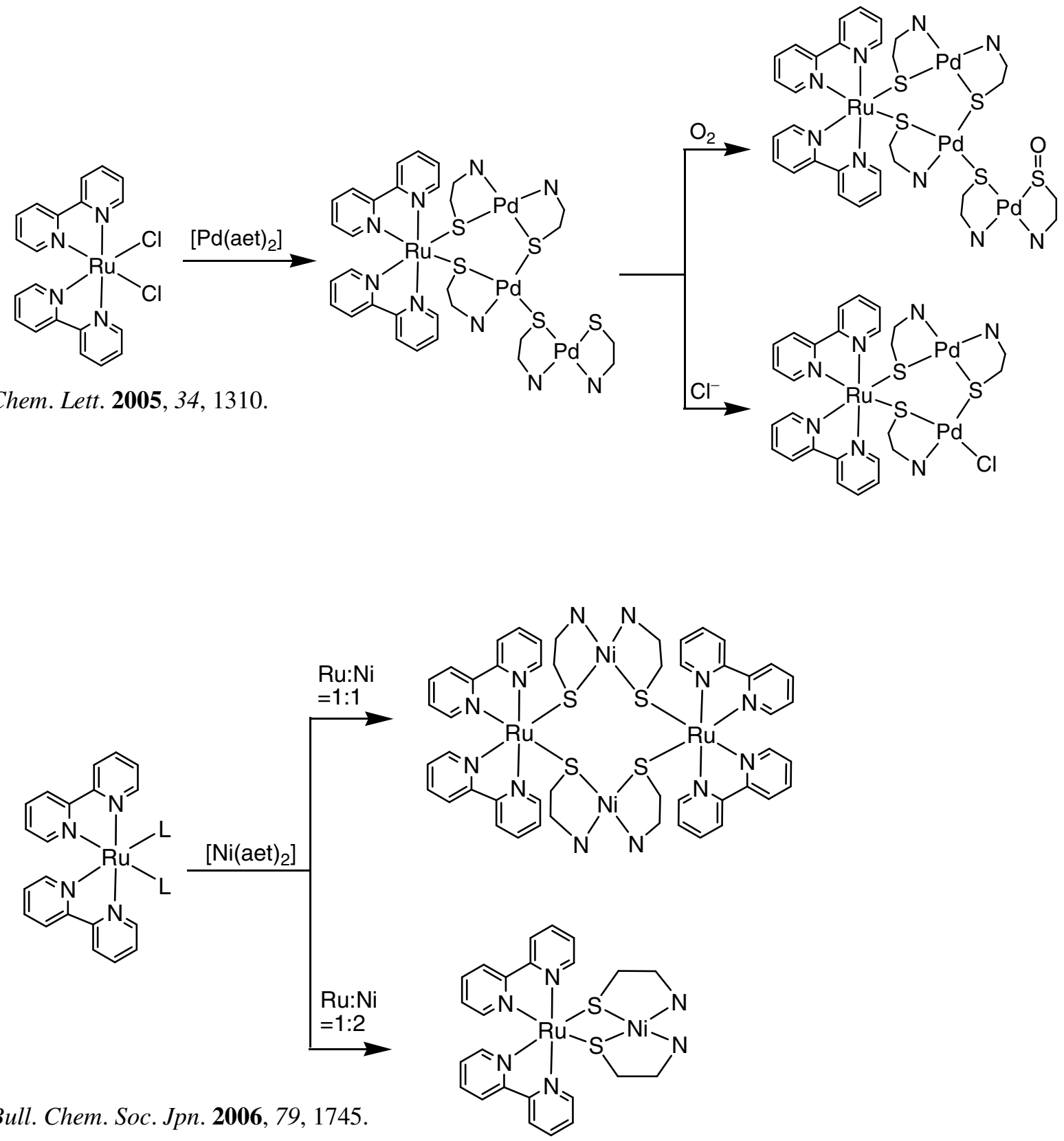